\title{
THE BRITISH ASSOCIATION FOR THE ADVANCEMENT OF SCIENCE
}

CIR JOHN COCKCROFT. president of the British $\$$ Association for the Advancement of Science, presided over a General Assembly of Section Committees in Birkbeck College, London, on January 5, when the plans for the scientific programme of the annual meeting at Manchester during August 29September 5 were completed and the work of the Association in recent months was surveyed.

Manchester, which last welcomed the British Association in 1915, is planning ambitiously for the meeting. The outstanding quality of the scientific faculties of the University and the College of Science and Technology, a large student population and the active intellectual life of the City and its surroundings all promise what may well be a record attendance. A full programme is being planned by the fifteen sections and for the wider public that will be reached by the two evening discourses by scientists of inter. national repute on the Friday and Monday of the meeting and by the closed-circuit colour television programmes screened by CIBA's 'Eidophor' process. With eight illustrated lectures and an open forum, the young people can almost be said to be having an annual meeting of their own; while the 'Science Fair' which they are staging will undoubtedly arouse great interest among onlookers and participants alike. Appointments to the Kelvin, Darwin and Lister lectureships have just been made. The Kelvin lecturer this year, Dr. B. E. J. Pagel, comes from the Royal Greenwich Observatory and will talk about "The Analysis of Starlight". "Bursts of Evolution" is the title suggested by Dr. M. R. House (University of Durham), the Darwin lecturer, and for the Lister lecture, Mr. R. A. French (University College, London) will take as his theme "The Changing Landscape of European Russia".

The Area Committees, which play so large a part in the task of presenting science continuously throughout the year, now cover practically the whole of Britain and two more are about to come into being - one sponsored by the Manchester Federation of Scientific Societies, and the other in Southampton, where the Association meets in 1964. Area Committees are planning, during the early part of 1962 , to hold a 'Science Fair' for school-children on Teesside and major 'Junior B.A. Meetings' (which will be attended by some thousands of young people) in Newcastle, Birmingham and in Belfast in June.
While the demands on the Association's Lecture Service continue unabated, and figures of audiences rise $(19,000$ in 114 lectures since last September) the most interesting development in this Service has undoubtedly been a 'circus' arranged in co-operation with the educational authorities in Devon in which three speakers lectured at six different centres in Devon to sixth-form audiences brought in from schools in the surrounding countryside. A similar experiment in Gloucestershire is being planned.

The Association's interest and influence in the educational field has once more been demonstrated by the highly successful conference staged last September, in co-operation with the Association of Teachers in Colleges and Departments of Education, on the teaching of science in the primary school.

The Association's symposium on world food and population problems at Cardiff has been followed by the publication of a booklet Hunger-Can it be Averted?, and the formation of a standing committee to study ways and means in which the Association might co-operate with the Freedom from Hunger campaign this year.

The Association's work in the field of visual aids has expanded rapidly, with some new developments and an increasing demand for the services already offered. As a result of the interest aroused by the survey of visual aids facilities in Essex secondary schools, a similar survey has been asked for in schools in Derby; while the receptions for science teachers at which specially selected prograrnmes of scientific films are shown are attracting larger and more appreciative audiences of teachers and local education authorities. One successful innovation at last year's meeting will be repeated in Manchester where (in addition to the continuous screening of scientific films for members) it is hoped to stage programmes of films selected by the Association in the theatre for the general public. These pioneering activities are having wide repercussions and not only in the United Kingdom itself; advice on visual aid problems is being sought from overseas, and a programme of scientific and technical films has been selected by the Association for distribution throughout Iceland by the State Film Library.

Further information about the Manchester Meeting or the Association's other activities can be obtained from the Secretary, British Association, 3 Sanctuary Buildings, Great Smith Street, S.W.1.

\section{THE INSTITUTE OF PHYSICS AND THE PHYSICAL SOCIETY}

\footnotetext{
$\mathrm{T}$ HE first annual report of the Council of the Institute of Physics and the Physical Society covers the period up to December 31,1960 , and incorporates reports of the activities of the Institute and of the Society during 1960 before the amalgamation of the two organizations on July 5, 1960*. The report, together with the financial statement and

* First Annual Report of the Council of the Institute of Physics and the Physical Society 1960. Pp. 23. (London: The Institute of Physics and the Physical Society, 1961.)
}

accounts, was presented to the annual general meeting of the amalgamated body held on July 4, 1961, at the headquarters of the Institute and Society, 47 Belgrave Square. London, and duly adopted.

The total membership of the Institute at the time of the amalgamation numbered 6,958 , and consisted of 5,560 in the professional grades of fellow, associate and graduate, and 1,398 students and subscribers. The corresponding figure for the Physical Society was 2,303 (1,913 fellows and 390 students) of whom 
812 were also membors of the Institute. By the end of 1960 the total membership of the amalgamated body had risen to 5,787 in the professional grades and 8,720 in the non-professional grades. Sixty-three oandidates wore successful in the 1960 graduateship examination: twenty-seven of these hold univorsity degrees and 35 the Higher National Certificate in applied physics. The fiftcen question papers set in the examination were published in tho September issue of the Bulletin of the Institute and Society. The new regulations governing the examination, which were published early in 1960 , were intended to apply first to the 1962 graduateship examination, but, in response to requests, an examination for the new Part 1 was agreed to be hold in 1961. Fortysix technical colloges presented candidates for the Ordinary National Certificate and twenty-nine colleges 355 candidates for the Higher National Certificate in appliod physics. Details of the results obtained appeared in the Decembor issue of the Bulletin. The report of the committeo set up by the Institute and the Society, with Prof. N. Kernmer as chairman, on the postgraduate training of physicists in British universities, has been published. In it serious criticisms wore mado of the quality of many Ph.D. physies graduates. The Council, and in particular Mr. N. Clarke, the deputy secretary of the amalgamated body, took a vory active part in the organization of the first international conference on "Physies Education" held during July-August in Paris, and in the preparation of the proceedings of the conference which havo now bcen published.

The conferences on classical and quantum turbulence at Oxford during March 21-22; on nuclear physics at the University of Livorpool during March $30-31$, and at the Univorsity of Glasgow during September 14-15; and on diamond physies at the Univorsity of Reading during September 22-23, were arranged by the Physical Society before its amalgamation with the Institute. The forty-fourth Guthrie Lecture was delivered by Prof. F. Hoyle on March 21 at Oxford, who took as his subject "Observational Tests in Cosmology". The text of the locturo has since been published in the Procedings of the Thysical Society (77, 1; 1961). Prof. F. Llewellyn Jones was the recipient of the sixteenth Charles Vernon Boys Prize on March 30 during the Liverpool conferenco, and Monsieur J. Brossel the fifteenth Holweck Medal and Prize (awarded by the Physical Society in conjunction with the Société Françaiso de Physique) on May 11 at Oxford. Tho addresses delivered by Prof. Jones and M. Brossel on the occasions of the presontation of the prizes are printed in the Year Book of the Physical Society for 1960. ('The series of Year Books has now been discontinued.) The tenth Rutherford Lecture, entitled "Studies of Nuclear Disintegrations at Very High Energies", was delivered by Prof. C. F. Powell during the Glasgow conforenco, and the thirty-soventh Duddell Medal awarded to Prof. R. V. Jonos for his contributions to the design of sensitive mechanical instruments and for his achievement in the growing of very large crystals was presented to him during the Reading conference. 'The Physical Society's annual exhibition of scientific instruments and apparatus was hold in the halls of the Royal Horticultural Socisty during January 18-20 with an attendance of more than 20,000 . There wero 140 exhibitors of whorn seven were representatives of universities or hospital modical schools. Nearly 5,000 copies of the official Handbook to the exhibition were sold.
Though the various publications, except for the Year Book, of both the Institute and the Society are to continue unaltered, the editorial organizations of the bodies have been integrated, because of the amalgamation, under the supervision of Dr. A. C. Stickland, editor and deputy secretary of the Institute and Society. In the annual report an analysis is given of the material submitted and published during 1960 in the monthly publications, Journal of Scientific Instruments, British Journal of Applied Physics, and Proceedings of the Physical Society. Both the Journals showed small increases in circulation, while that of the Proceedings remained about the same. Volume 23 (1960) of the annual reports of Progress in Physics was published in June: it contained ten articles and reprints of the individual articles were again available for separate purchaso. New books published for the Instituto included a revised edition of X-ray Diffraction by Polycrystalline Materials, first published in 1955 in tho Physics in Industry series; A Physics Anthology consisting of a selection of articles from tho Institute's Bulletin, compiled by Mr. N. Clarke; and Laboratory and Workshop Notes 1956-58, the fifth in the series of compilations by Dr. Ruth Lang of notes from the Journal of Scientific Instruments.

At the annual dinner of the Institute hold on May 3, 1960, at the Park Lane Hotel, London, 327 members and gucsts were present. Sir George Thomson presided, and the speakers were Sir Roger Makins, Dr. C. Sykes and Mr. J. A. Ratcliffe. Âbout sixty fellows of the Physical Society were present at the annual luncheon held during the exhibition of scientific instruments and apparatus.

As usual, a section of the annual report is devoted to an account of the activities of the eleven branches and eleven specialist groups of the organization. The Australian Branch, consisting of six divisions, was responsible for a total of about sixty meetings, some held jointly with other scientific bodies. The exhibition of scientific instruments held by the Now South Wales Division attracted an attendance of over 2,500, and tho South Australian Division was honoured by a visit from Sir Lawrence Bragg, who delivered the fourth Einstein Memorial Lecture. The activities of the Malayan Branch wore confinod to its members attending colloquia in the Physics Department of the University of Malaya. The London and Home Counties Branch visited the laboratories of the British Electrical and Allied Industries Research Association at Leathorhead in April, the Clarendon Laboratory, Oxford, in June, and the Ewell County Tochnical College in October. A symposium on now materials was hold in Novombor. Tho Midland Branch held a joint symposium with the Education Group during Easter on the training of the industrial physicist. Five of the oloven talks given by the Scottish Branch in Glasgow formed the first part of a series of lectures devoted to new techniques, and in Octobor a conference was held in conjunction with tho Scottish Education Department to discuss the teaching of physics with special reference to the National Certificate courses in applied physics. The conforence was addressed by Dr. J. H. I.onihan, and a report of tho mooting, dirccting attention to the seriousness of the present situation, was forwarded to the Couneil of the Institute and Society. Both the Acoustics and Colour Groups were exhibitors at the Physical Society's annual exhibition, the subjects being vibra. tions and colour adaptation, respectivoly. The activities of the Eloctronics Group included a meet- 
ing in conjunction with the Radio Spectroscopy Group during Easter at the University of Nottingham on the subject of solid-state amplifiers, and with the Low Temperature Group (November 15) to discuss electronic devices for helium temperatures.

The accounts presented in the annual report show that the amalgamation cost the new body and its predecessors $£ 1,420$, of which about half was for legal expenses. On July 13, 1960, at its first meeting, the Council of the new organization established "The Physics Trust Fund", the object of which is to finance the educational and scientific work of the Institute and Society, including the production and publication of its scientific periodicals and its meet- ings. The fund has been recognized as a charity by the Commissioners of Inland Revenue although the parent body has not. To finance its increasing activities, the Institute and Society launched an appeal for $£ 140,000$, and by the end of 1960 the total in gifts and covenanted promises received amounted

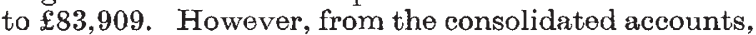
which aro included in order to give a simple general picture of the financial position at December 31, 1960 , and of the year's working, it is clear that the reserves available to the Council are still in need of substantial increase if the programme planned for the expansion and improvement of the activities of the Institute and Society is to be maintained.

S. Weintroub

\section{BRITISH RESEARCH ON THE HIGH ATMOSPHERE}

\begin{abstract}
r. $\mathrm{TE}$ Meteorological Office programme of research on the high atmosphere is summarized by Dr. R. Frith in the Meteorological Office report for the year ending December 31, 1960*. The object of the research is to examine the variations of meteorological parameters in the high atmosphere and to attempt to link them with what takes place at lower levels. 'The problem is being attacked in several ways. First, the occurrence of strong very turbulent winds at $75-110 \mathrm{~km}$. has been disclosed from the study of ionized trails left by meteors. The large number of observations, mostly obtained by a team at the University of Manchoster, is being examined systematically. Secondly, it is hoped to make routine rocket soundings up to at least sixty kilometres by the end of 1962. The rockets will release a temperature sonde at apogee and the descent will be controlled by a special type of parachute, which will also act as a radar target, so enabling the winds to be measured. It is hoped to use larger rockets to eject 'window', or a sphere, so as to obtain wind measurements at higher levels during 1963. The grenade method, whereby gronades are ejected from a rocket and exploded at intervals, may also be tried in order to obtrain mean winds and temperatures between the levels of suecessive explosions.
\end{abstract}

* Annual Report on the Meteorological Office for the year January 1 to December 31, 1960. Pp. 67+4 plates. (M.0. 710.) (London: H.M. Stationery Offiee, 1961.) $4 s$. 6d. net.
A third research method is already in operation experimentally. It is possible to deduce the air density at a given level by measuring the light scattered at that level from a powerful searchlight beam, provided the air at and above thirty kilometres, at which height the density is known from radiosonde determinations, is 'clean'. Experiments over a $40 \mathrm{~km}$. base-line across Cardigan Bay have revealed unexpectedly large scattering above 60 $\mathrm{km}$. This may be due to dust, but is so far unexplained.

Fourthly, the Meteorological Office is at present building and testing instruments for use on the second British satellite, to be put into orbit in 1963 by an American Scout rocket. The aim is to measure the vertical distribution of ozone, using sensors which respond only to radiation in one of the ozone absorption bands. Mostly, a satellite is either in complete sunlight or complete darlness, and no measurements ean then be obtained. Since the satellite will be in orbit beyond the ozone layer it will see the Sun for about a minute twice on each orbit, through varying thicknesses of atmosphere. It is in these $2 \mathrm{~min}$. that useful measurements can be obtained. It is hoped to obtain information, particularly below $40 \mathrm{~km}$., where the life of ozone molecules is long enough to enable ozone to be used as a meteorological tracer, thereby providing information on the general circulation and vertical motion in this little-known region.

\section{UPPER ATMOSPHERE RESEARCH IN AUSTRALIA}

\begin{abstract}
A S a supplement to the thirteenth annual report A of the Commonwealth Scientific and Industrial Research Organization, Australia (see Nature, 192, $712 ; 1961)$, the report of the Upper Atmosphere Section for the year ended June 30, 1961, has recently been published*. This Section, under Dr. D. F. Martyn, with headquarters at Harben Vale, Camden, New South Wales, is concerned with investigation of the atmosphere above about $50 \mathrm{~km}$. by various experimental methods involving radio and optical techniques. The small changes of the Earth's mag. netic field due to electric currents in the ionosphere

* Commonwealth of Australia. Commonwenlth Seientific and Industrial Research Organization. Upper Atmosphere Section Annual Canberra, Adelaide, Camden: C.S.I.R.O., 1961.)
\end{abstract}

have also been under investigation. During the past year the programme of work has been increasingly directed towards the measurement of phenomena of the upper atmosphere by the use of rockets and satellites.

Several field stations have been equipped with rotating-loop direction finders for locating the sources of low-frequency atmospheric noise, the intensity of which is also measured over a frequency-range of $1-40 \mathrm{kc} . / \mathrm{s}$., special attention being given to the background noise in the band 4-6 kc./s.

On moonless nights the sky is still faintly illuminated, partly by airglow caused by the self-luminescence of the gases in the upper atmosphere. The strongest spectral lines in the airglow are the green and red lines emitted by atomic oxygen at wave- 